\title{
An Unusual Michael-Induced Skeletal Rearrangement of a Bicyclo[3.3.1]nonane Framework of Phloroglucinols to a Novel Bioactive Bicyclo[3.3.0]octane
}

\author{
Veroniki P. Vidalii, ${ }^{\dagger}$ Kornilia P. Mitsopoulou, ${ }^{\dagger, \ddagger}$ Marianna Dakanali, ${ }^{\ddagger},{ }^{\circ}$ \\ Konstantinos D. Demadis, ${ }^{\S}$ Andreani D. Odysseos, ${ }^{\|, \perp}$ Yiota A. Christou, ${ }^{\|, \perp}$ and \\ Elias A. Couladouros ${ }^{*, \neq}$ \\ Synthesis and Bioorganic Chemistry, NCSR "Demokritos", 15310 Ag. Paraskevi, \\ Athens, Greece, Chemical Laboratories, Agricultural University of Athens, Iera Odos 75, \\ 118 55, Athens, Greece, Crystal Engineering, Growth \& Design Laboratory, Department \\ of Chemistry, University of Crete, P.O. Box 2208, GR-71003 Heraklion, Crete, Greece, \\ EPOS-Iasis, R\&D, 5 Karyatidon Street, 2028, Nicosia, Cyprus, and University of \\ Cyprus, 75 Kallipoleos Avenue, 1678 Nicosia, Cyprus
}

ecoula@aua.gr

Received July 24, 2013

ABSTRACT

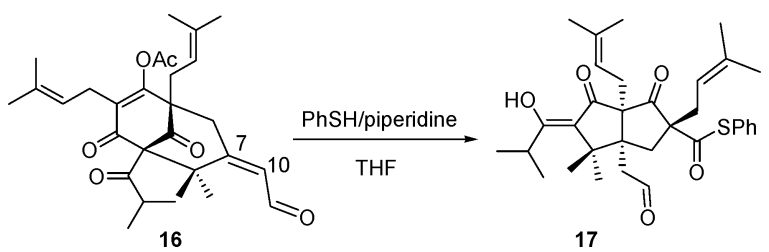

A novel skeletal rearrangement of bicyclo[3.3.1]nonane-2,4,9-trione (16) to an unprecedented highly functionalized bicyclo[3.3.0]octane system (17), induced by an intramolecular Michael addition, is presented. This novel framework was found to be similarly active to hyperforin (1), against PC-3 cell lines. A mechanistic study was examined in detail, proposing a number of cascade transformations. Also, reactivity of the $\Delta^{7,10}$-double bond was examined under several conditions to explain the above results.

Polycyclic polyprenylated acylphloroglucinols (PPAPs) contain a bicyclo[3.3.1]nonane framework, which is often found in nature, as a constituent of many biologically active metabolites. ${ }^{1}$ The chemistry of this carbon skeleton has been intensively explored for the

\footnotetext{
${ }^{\dagger}$ NCSR "Demokritos".

Agricultural University of Athens.

${ }^{\S}$ University of Crete.

"EPOS-Iasis, R\&D.

${ }^{\perp}$ University of Cyprus.

Department of Radiology, University of Texas Southwestern Medical Center, Dallas, TX 75390-8542.

(1) For recent reviews referring to biological activity, biosynthesis, and synthetic efforts towards PPAPs, see: (a) Ciochina, R.; Grossman, R. B. Chem. Rev. 2006, 106, 3963. (b) Singh, I. P.; Sidana, J.; Bharate, S. B.; Foley, W. J. Nat. Prod. Rep. 2010, 27, 393. (c) Dakanali, M.; Theodorakis, E. A. Polyprenylated Phloroglucinols and Xanthones, in Biomimetic Organic Synthesis; Wiley-VCH: Weinheim, 2011. (d) Njadarsom, J. T. Tetrahedron 2011, 67, 7631. (e) Richard, J. A.; Pouwer, R. H.; Chen, D. Y. K. Angew. Chem., Int. Ed. 2012, 51, 4536.
}

construction of complex natural products, as well as various ring systems. ${ }^{2}$

Particularly, the great biological properties of hyperforin (1), garsubelin A (2), and other PPAPs (Figure 1) have intrigued many researchers to focus on the total synthesis

(2) For publications towards the synthesis of the bicyclo[3.3.1]nonane-2,4,6-trione core of PPAPs, see: (a) Nicolaou, K. C.; Pfefferkorn, J. A.; Cao, G.-Q.; Sanghee, K.; Kessabi, J. Org. Lett. 1999, 1, 807. (b) Nicolaou, K. C.; Pfefferkorn, J. A.; Kim, S.; Wei, H. X. J. Am. Chem. Soc. 1999, 121, 4724. (c) Abe, M.; Nakada, M. Tetrahedron Lett. 2007, 48, 4873. (d) Ciochina, R.; Grossman, R. B. Org. Lett. 2003, 5, 4619. (e) Kraus, G. A.; Dneprovskaia, E.; Nguyen, T. H.; Jeon, I. Tetrahedron 2003, 59, 8975. (f) Kraus, G. A.; Jeon, I. Tetrahedron 2005, 61, 2111. (g) Kraus, G. A.; Nguyen, T. H.; Jeon, I. Tetrahedron Lett. 2003, 44, 659. (h) Mehta, G.; Bera, M. K. Tetrahedron Lett. 2004, 45, 1113. (i) Mehta, G.; Bera, M. K. Tetrahedron Lett. 2008, 49, 1417. (j) Mehta, G.; Bera, M. K.; Chatterjee, S. Tetrahedron Lett. 2008, 49, 1121. (k) Nicolaou, K. C.; Carenzi, G. E. A.; Jeso, V. Angew. Chem., Int. Ed. 2005, 44, 3895. (1) Young, D. G. J.; Zeng, D. J. Org. Chem. 2002, 67, 3134. (m) Wang, D.; Crowe, W. E. Org. Lett. 2010, 12, 1232. (n) Mehta, G.; Dhanbal, T.; Bera, M. K. Tetrahedron Lett. 2010, 51, 5302. 
of these natural products, ${ }^{3}$ as well as on the preparation of analogues for SAR studies. ${ }^{4}$ Our approach to the bicyclo[3.3.1]nonane system of type A PPAPs is depicted in Scheme 1. The fully functionalized carbon skeleton of hyperforin (1) and garsubelin A (2) was constructed in three steps, employing the readily available deoxycohumulone $5 .^{5}$

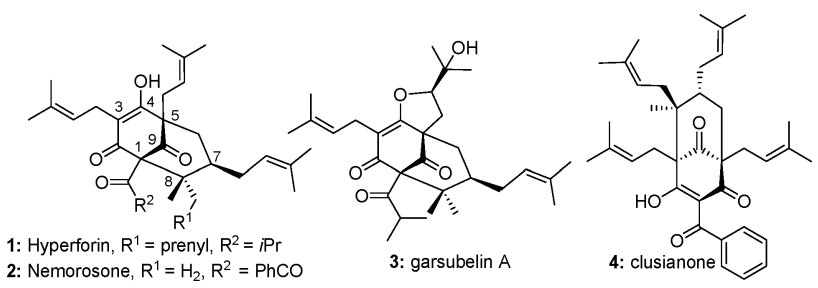

Figure 1. Natural PPAPs.

Scheme 1. Synthetic Approach to Type A PPAPs

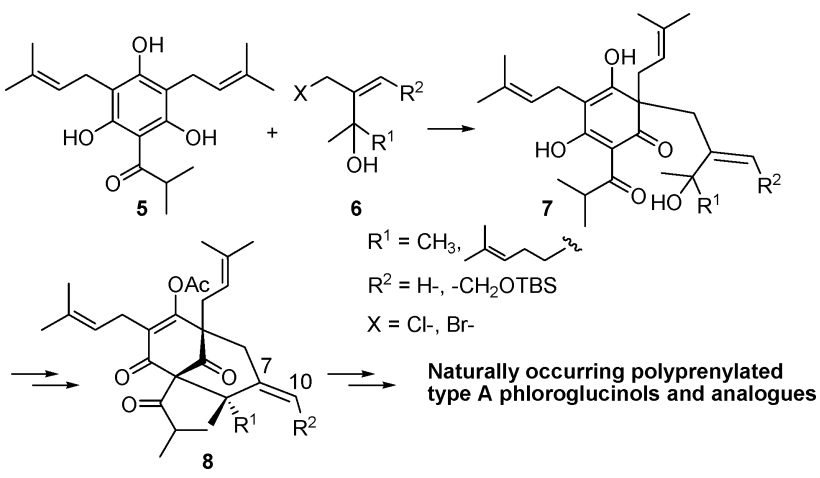

Consequently, our research efforts focused on the removal of the remaining $\Delta^{7,10}$-double bond from the bicyclic system $\mathbf{8}$, in a regioselective manner. However, the neopentyl position of this exocyclic double bond proved

(3) For total synthesis of hyperforin, see: (a) Sparling, B. A.; Moebius, D. C.; Shair, M. D. J. Am. Chem. Soc. 2013, 135, 644. (b) Shimizu, Y.; Shi, S. L.; Usuda, H.; Kanai, M.; Shibasaki, M. Angew. Chem., Int. Ed. 2010, 49, 1103. (c) Uwamori, M.; Nakada, M. Tetrahedron Lett. 2013, 54, 2022. For total syntheses of garsubelin A, see: (d) Kuramochi, A.; Usada, H.; Yamatsugu, K.; Motomu, K.; Shibasaki, M. J. Am. Chem. Soc. 2005, 127, 14200. (e) Siegel, D. R.; Danishefsky, S. J. J. Am. Chem. Soc. 2006, 128, 1048. For a total synthesis of nemorosone and clusianone, see: (f) Tsukano, C.; Siegel, D. R.; Danishefsky, S. J. Angew. Chem., Int. Ed. 2007, 46, 840. For synthesis of a type B PPAP, clusianone, see: $(\mathrm{g})$ Rodeschini, V.; Ahmad, N. M.; Simpkins, N. S. Org. Lett. 2006, 8, 5283. (h) Nuhant, P.; David, M.; Pouplin, T.; Marazano, C. Org. Lett. 2007, 9 , 287. (i) Qi, J.; Porco, J. A., Jr. J. Am. Chem. Soc. 2007, 129, 2682. For total synthesis of plukenetione, see: (j) Zhang, Q.; Mitasev, B.; Qi, J.; Porco, J. A., Jr. J. Am. Chem. Soc. 2010, 132, 14212.

(4) For analogues and SAR studies, see: (a) Verotta, L.; Appendino, G.; Belloro, E.; Jakupovic, J.; Bombardelli, E. J. Nat. Prod. 1999, 62, 770. (b) Verotta, L.; Appendino, G.; Jakupovic, J.; Bombardelli, E. J. Nat. Prod. 2000, 63, 412. (c) Shan, M. D.; Hu, L. H.; Chen, Z. L. J. Nat. Prod. 2001, 64, 127. (d) Verotta, L.; Appendino, G.; Belloro, E.; Bianchi, F.; Sterner, O.; Lovati, M.; Bombardelli, E. J. Nat. Prod. 2002, 65, 433. (e) Gartner, M.; Muller, T.; Simon, J. C.; Giannis, A.; Sleeman, J. P. ChemBioChem 2005, 6, 171.

(5) Couladouros, E. A.; Dakanali, M.; Demadis, K. D.; Vidali, V. P. Org. Lett. 2009, 11, 4430. to be an unsurpassed obstacle. Many attempts to remove the $\Delta^{7,10}$-double bond (Table 1) via either hydrogenation (entries 1-3) or regioselective isomerization of an allylic alcohol to the corresponding carbonyl compound (entries $4,5)^{6}$ proved unsuccesful. The difficulty in accessing C-7 was further revealed during the attempted 3,3-sigmatropic rearrangement of allylic thiocarbonate ester $\mathbf{1 3}$ (entry 6). The molecule refused to furnish a saturated C-7 through the expected 1,2-sigmatropic rearrangement ${ }^{7}$ yielding instead ester $\mathbf{1 4}$ via an 1,3-sigmatropic rearrangement.

Table 1. Selected Examples of Attempts on $\Delta^{7,10}$-Double Bond Removal $^{a}$
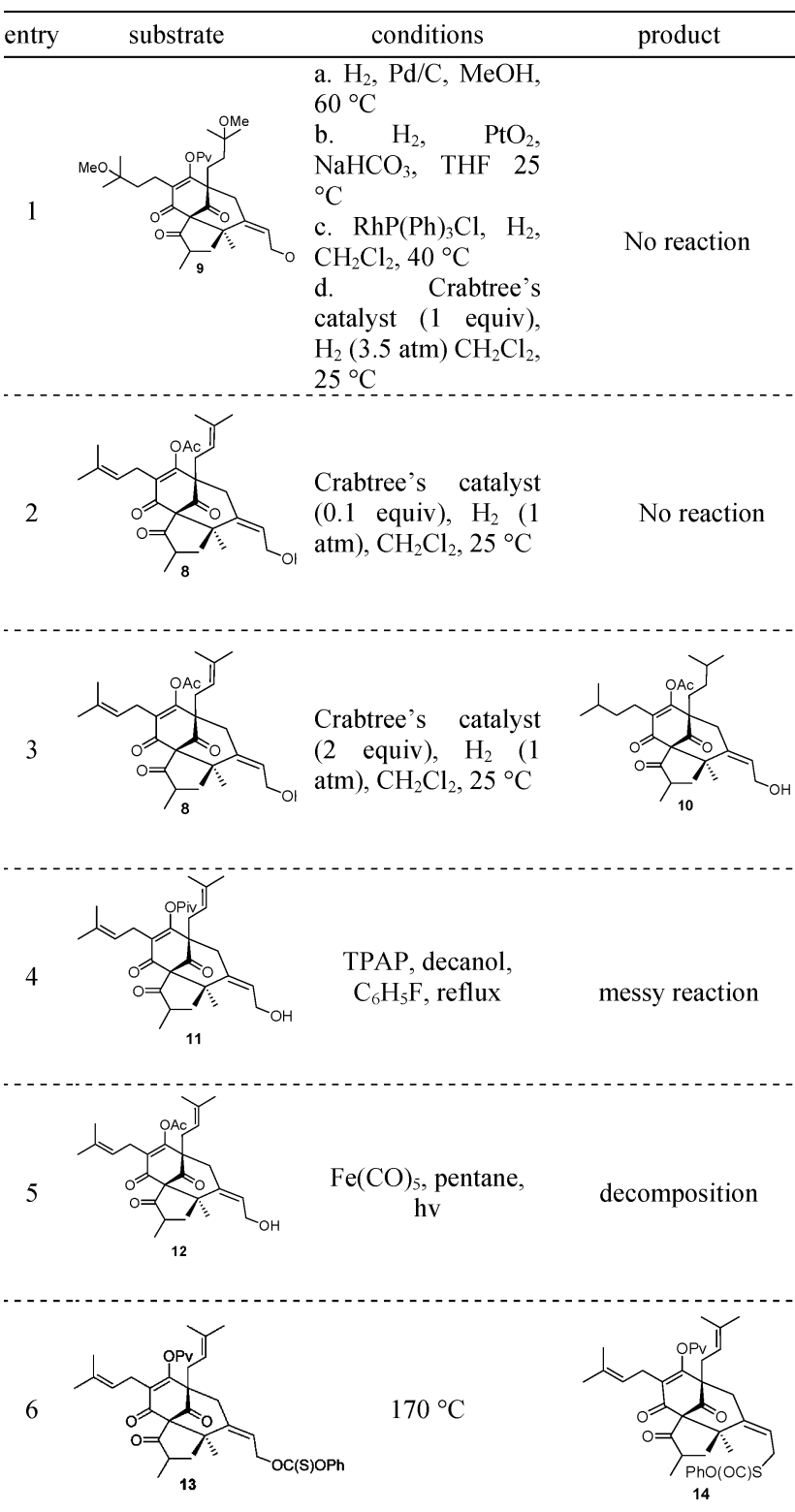

${ }^{a}$ Crabtree's catalyst $=\left[\operatorname{Ir}(\mathrm{COD}) \mathrm{Py}\left(\mathrm{PCy}_{3}\right)\right] \mathrm{PF}_{6}$.

(6) (a) Marko, I. E.; Gautier, A.; Tsukazaki, M.; Llobet, A.; PlantalechMir, E.; Urch, C. J.; Brown, S. M. Angew. Chem., Int. Ed. 1999, 38, 1960. (b) Cherkaoui, H.; Soufiaoui, M.; Gree, R. Tetrahedron 2001, 57, 2379.

(7) (a) Crich, D.; Yang, F. J. Org. Chem. 2008, 73, 7017. (b) Subramanian, V.; Moume-Pymbock, M.; Hu, T.; Crich, D. J. Org. Chem. 2011, 76, 3691. 
Scheme 2. Michael Approach to PPAPs
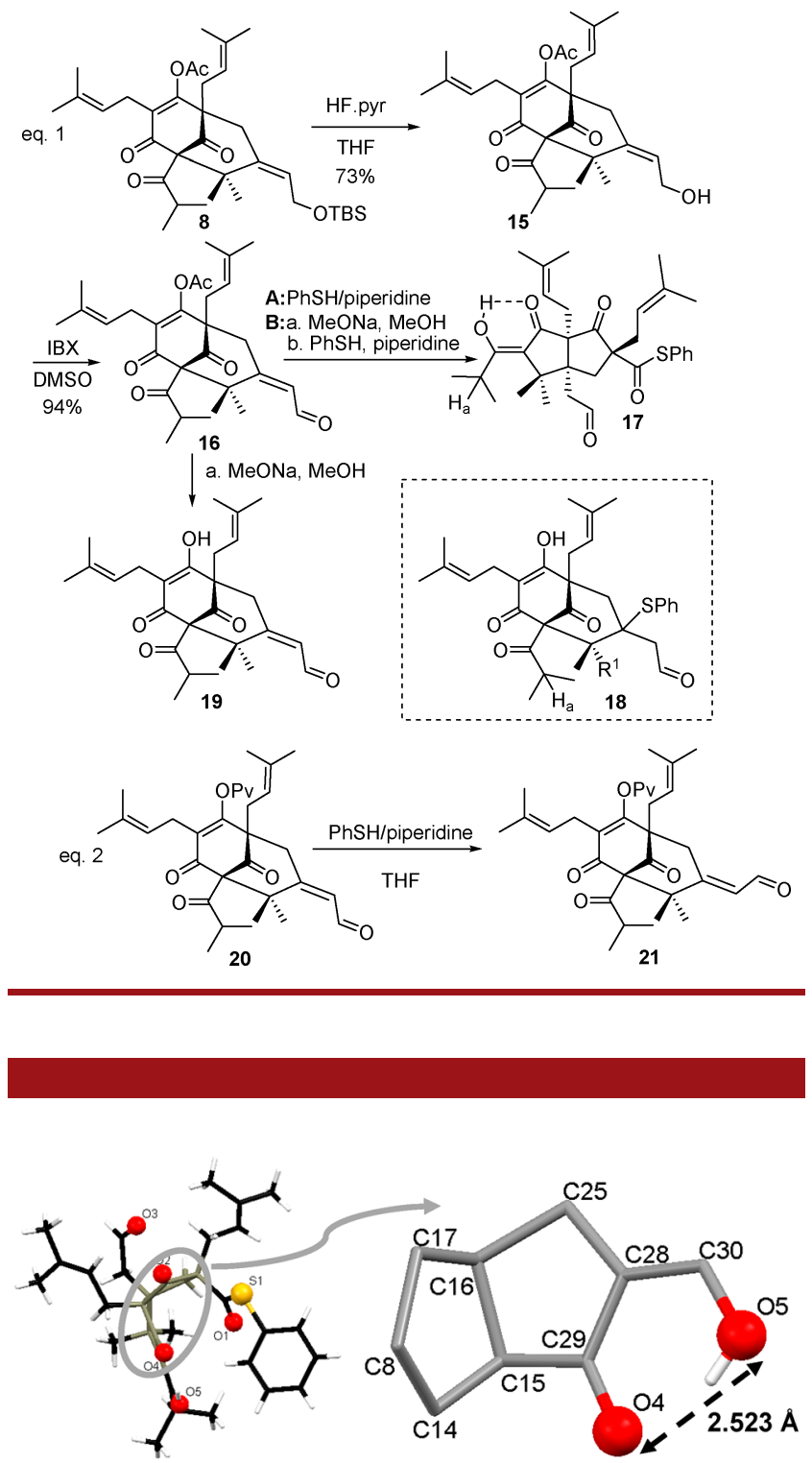

Figure 2. Molecular structure of $\mathbf{1 7}$ (left) and detailed view of the bicyclic core with the intramolecular $\mathrm{H}$-bond (right). $\mathrm{O}$ (red) and $\mathrm{S}$ (yellow) atoms are presented as exaggerated spheres.

In parallel, further differentiation of the $\Delta^{7,10}$-double bond of system 8 was attempted, by converting it to the more polarized $\alpha, \beta$-unsaturated aldehyde 16, after desilylation and oxidation of $\mathbf{1 5}$ (Scheme 2). All attempted conditions are summarized in Table 2. Typical Michael conditions (e.g., $\mathrm{PhSH}, \mathrm{Et}_{3} \mathrm{~N}, \mathrm{THF}$ ) resulted in messy reaction mixtures (Table 2 , entries $6-8){ }^{8}$

After several attempts, subjection of $\mathbf{1 6}$ to $\mathrm{PhSH} /$ piperidine (Scheme 2, eq 1, method A) furnished a single product, whose ${ }^{1} \mathrm{H}$ NMR spectrum supported the desired deacetylated structure 18, except for a significant shift observed for Ha $(\delta 2.04 \rightarrow 2.78)$. To our surprise, X-ray

(8) Other attempts for hydride addition on $\alpha, \beta$-unsaturated alcohol 11 (e.g., $\left[\left(\mathrm{PPh}_{3}\right) \mathrm{CuH}\right]_{6}$ or $\left.\mathrm{NaBH}_{4} / \mathrm{AcOH}\right)$ also failed.
Table 2. Michael Addition Attempts on Aldehyde $\mathbf{1 6}$

\begin{tabular}{|c|c|c|c|}
\hline entry & base/Nu/solvent & $t$ & $\begin{array}{l}\text { product } \\
\text { (\% yield) }\end{array}$ \\
\hline 1 & -/PhSH/THF & 25 to $60^{\circ} \mathrm{C}$ & no reaction \\
\hline 2 & $-/ \mathrm{PhSH} / \mathrm{CH}_{2} \mathrm{Cl}_{2}$ & 25 to $40^{\circ} \mathrm{C}$ & no reaction \\
\hline 3 & $-/ \mathrm{PhSH} /-$ & 25 to $60^{\circ} \mathrm{C}$ & no reaction \\
\hline 4 & pyridine/PhSH/THF & 25 to $60^{\circ} \mathrm{C}$ & no reaction \\
\hline 5 & PPTS/PhSH/THF & 0 to $60^{\circ} \mathrm{C}$ & no reaction \\
\hline 6 & DMAP/PhSH/THF & $25^{\circ} \mathrm{C}$ & messy reaction $^{a}$ \\
\hline 7 & $\mathrm{Et}_{3} \mathrm{~N} / \mathrm{PhSH} / \mathrm{THF}$ & 0 to $25^{\circ} \mathrm{C}$ & messy reaction ${ }^{a}$ \\
\hline 8 & $\mathrm{Et}_{3} \mathrm{~N} / \mathrm{PhSH} / \mathrm{CH}_{2} \mathrm{Cl}_{2}$ & 0 to $25^{\circ} \mathrm{C}$ & messy reaction $^{a}$ \\
\hline 9 & $\begin{array}{l}\text { a. } \mathrm{MeONa} / \mathrm{MeOH} \\
\text { b. } \mathrm{DBU} / \mathrm{PhSH} / \mathrm{THF}\end{array}$ & $25^{\circ} \mathrm{C}$ & no reaction \\
\hline 10 & piperidine/PhSH/THF & $25^{\circ} \mathrm{C}$ & $\mathbf{1 7}(73 \%)$ \\
\hline 11 & $\begin{array}{l}\text { a. } \mathrm{MeONa} / \mathrm{MeOH} \\
\text { b. piperidine/PhSH/THF }\end{array}$ & $25^{\circ} \mathrm{C}$ & $\mathbf{1 7}(81 \%)$ \\
\hline 12 & $\begin{array}{l}\text { a. } \mathrm{MeONa} / \mathrm{MeOH} \\
\text { b. } \mathrm{Bu}_{2} \mathrm{NH} / \mathrm{PhSH} / \mathrm{THF}\end{array}$ & $25^{\circ} \mathrm{C}$ & $17(70 \%)$ \\
\hline 13 & $\begin{array}{l}\text { a. } \mathrm{MeONa} / \mathrm{MeOH} \\
\text { b. } \mathrm{BuNH}_{2} / \mathrm{PhSH} / \mathrm{THF}\end{array}$ & $25^{\circ} \mathrm{C}$ & $17(79 \%)$ \\
\hline 14 & $\mathrm{MeONa} / \mathrm{MeOH}$ & $25^{\circ} \mathrm{C}$ & 19 \\
\hline
\end{tabular}

analysis revealed the structure of the deacetylated 5,5bicyclic framework 17 (Figure 2), which is locked in an intramolecular hydrogen bonded ring $(\mathrm{O} \cdots \mathrm{O} 2.523 \AA)$, explaining $\mathrm{Ha}$ deshielding (see Supporting Information (SI) for complete experimental details).

Further experimentation on Michael coupling conditions was needed in order to clarify the mechanism of the new reaction. Application of the same conditions on the pivaloate derivative $\mathbf{2 0}$ (Scheme 2, eq 2) resulted only in $\Delta^{7,10}$-double bond isomerization product $\mathbf{2 1}$, proving that protective group removal was necessary for the rearrangement to proceed. Additionally, deprotection of $\mathbf{1 6}$ using $\mathrm{MeONa} / \mathrm{MeOH}$ resulted in the formation of unstable alcohol 19 which was subsequently converted to $\mathbf{1 7}$ using $\mathrm{PhSH} /$ piperidine.

Several other bases were also used (Table 2), clarifying that this skeletal rearrangement is not related to $\mathrm{pH}$, but it proceeds only in the presence of a primary or a secondary amine (entries $10-13$ vs entries 6-9).

The latter findings suggest the formation of a possible imine intermediate. Accordingly, we propose the following mechanism (Scheme 3). The exposed allylic aldehyde 19 should be the most accessible carbonyl against amines. Imine formation of the above moiety augments the electrophilicity at C-7, enabling thus an attack of the C-3 enolate anion, derived from the resonated unprotected $\mathrm{C}-4$ hydroxyl group $(\mathbf{2 2} \rightarrow \mathbf{2 3})$. Had this highly strained tricyclic system 23 been formed, it may release strain via eight possible retro-aldol reactions (two from C4-carbonyl, three from $\mathrm{C} 2$-carbonyl, and three from C9-carbonyl). Cleavage of $\mathrm{C} 1-\mathrm{C} 9$ or $\mathrm{C} 1-\mathrm{C} 2$ bonds (pathway 1 or 2 ) should be more favorable, since they both could lead to a delocalized enolate system. Noticeably, out of all the possible derivatives, $\mathbf{2 3}$ affords the 5,5-ring system $\mathbf{2 4}$ versus the 6,5-ring system $\mathbf{2 5}$, in a high yield. 
Scheme 3. Proposed Mechanism of Michael-Induced Skeleton Rearrangement
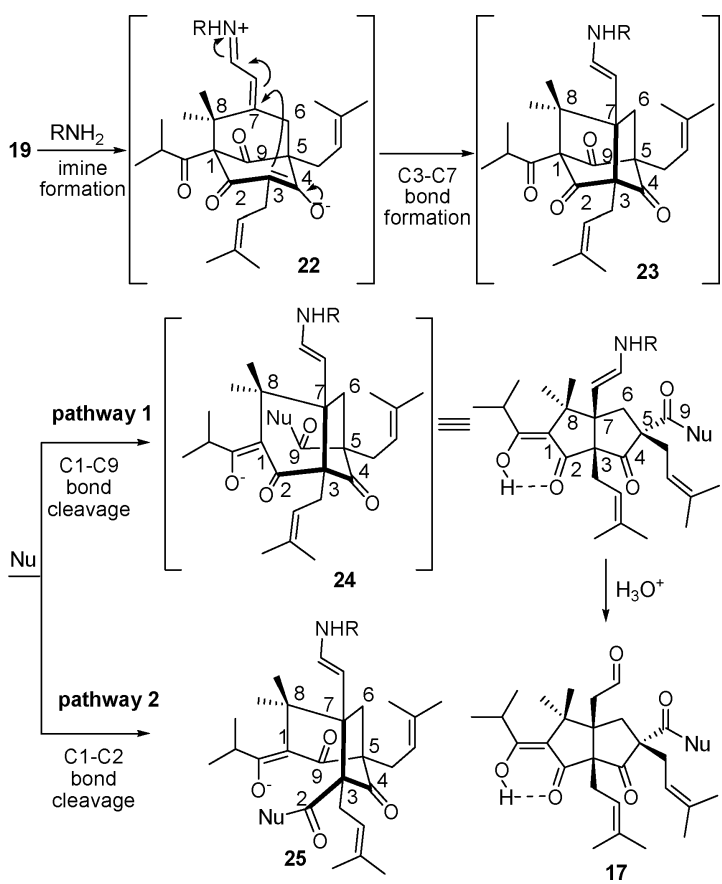
$\mathrm{H}_{3} \mathrm{O}^{+}$

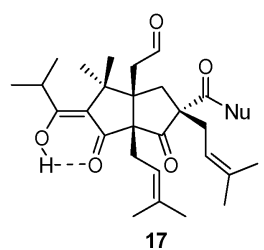

Preliminary screening of this novel framework was performed. Hyperforin (1) and its derivatives have been reported to show target specific antitumor activity through the Akt1-mediated antiproliferative and apoptotic pathway. ${ }^{9}$ Thus, $\mathbf{1}$ and $\mathbf{1 7}$ were assessed for antiproliferative activity in the androgen-unresponsive, grade IV, PC-3 cell line. PC-3 cells are highly metastatic with constitutive expression of the EGFR oncogene and downstream

(9) (a) Merhi, F.; Tang, R.; Piedfer, M.; Mathieu, J.; Bombarda, I.; Zaher, M.; Kolb, J. P.; Billard, C.; Bauvois, B. PLoS One 2011, 6, e25963. (b) Sun, F.; Liu, J. Y.; He, F.; Liu, Z.; Wang, R.; Wang, D. M.; Wang, Y. F.; Yang, D. P. J. Asian Nat. Prod. Res. 2011, 13, 688. (c) Vraka, P. S.; Drouza, C.; Rikkou, M. P.; Odysseos, A. D.; Keramidas, A. D. Bioorg. Med. Chem. 2006, 14, 2684. (d) Huang, P. H.; Chuang, H. C.; Chou, C. C.; Wang, H.; Lee, S. L.; Yang, H. C.; Chiu, H. C.; Kapuriya, N.; Wang, D.; Kulp, S. K; Chen, C. S. Sci. Signal. 2013, 6, 267.
Table 3. Antiproliferative Efficacy (IC in $\mu \mathrm{g} / \mathrm{mL}$ )

\begin{tabular}{lccc}
\hline compound & $\mathrm{IC}_{20}$ & $\mathrm{IC}_{50}$ & $\mathrm{IC}_{80}$ \\
\hline$\alpha$-TOS & \\
1 & 17.25 & 43.13 & 69.01 \\
17 & 7.54 & 18.85 & 30.17 \\
\multicolumn{2}{c}{$\alpha$-TOS $=\alpha$-tocopherol succinate. } & & 38.48 \\
\multicolumn{2}{r}{$r$} & & \\
\hline
\end{tabular}

activation of the Akt1 pathway. Surprisingly, compound 17 showed similar antiproliferative efficacy with $\mathbf{1}$ (Table 3 ), while both were more potent than reference compound $\alpha-\operatorname{TOS}^{9}(\mathrm{SI})$.

In conclusion, the reactivity of the $\Delta^{7,10}$-double bond of bicyclic acyl phloroglucinol systems $\mathbf{8}$ and $\mathbf{1 6}$ were examined, under various conditions. Due to severe steric hindrance, the only successful tranformation was that to the bicyclic[3.3.0] octane system via an intramolecular rearrangement. The above findings open a new route to a novel class of bioactive acylphloroglucinol analogues. Current efforts focus on extending the utility of this novel transformation, as well as further dissecting the molecular mechanism of its bioactivity.

Acknowledgment. This work was supported by the COST Action CM 0804 and the European Union (European Social Fund - ESF) and Greek national funds through the Operational Program "Education and Lifelong Learning" of the National Strategic Reference Framework (NSRF) - Research Funding Program: Heracleitus II. Investing in Knowledge Society through the European Social Fund.

Supporting Information Available. Experimental details and characterization data for all new compounds, as well as crystallographic data (cif file, deposited in the CCDC as 912255) and bioactivity data for $\mathbf{1 7}$ and $\mathbf{1}$. This material is available free of charge via the Internet at http://pubs.acs.org.

The authors declare no competing financial interest. 